Annals of Warsaw University of Life Sciences - SGGW

Land Reclamation No 47 (2), 2015: 153-161

(Ann. Warsaw Univ. Life Sci. - SGGW, Land Reclam. 47 (2), 2015)

\title{
Vertical and horizontal permeability measurements in organic soils
}

\author{
EDYTA E. MALINOWSKA, ALOJZY SZYMAŃSKI \\ Laboratory of Water Centre, Faculty of Civil and Environmental Engineering \\ Warsaw University of Life Sciences - SGGW
}

\begin{abstract}
Vertical and horizontal permeability measurement in organic soils. The paper is referring to vertical and horizontal laboratory permeability measurements in soft organic soils. The estimation of anisotropic permeability in soft organic soils, as peats, requires to use a special apparatus and the knowledge of proper analysis of the test results. During loading the void ratio decreases substantially that causes the changeability of the permeability. The change of permeability during the compression is very important because of the influence of the consolidation coefficient. Initial strain in soft organic soils appears very quickly, just after loading, and brings immediately the decrease of permeability. In most of the estimations, it is assumed that during the consolidation process the water flows just in the vertical direction. In soft organic soils, like peats, the consolidation theory should consider the changes of mechanical and physical properties in consolidation period, in both directions. The direct measurement of vertical and horizontal permeability of organic soil and the non-Darcian flow theory may be of considerable importance in estimating pore water pressure dissipation, and settlement rates in the consolidation model. In the paper, the method of investigation and the test results of the vertical and horizontal permeability are presented. The Modified Rowe Cell Set for obtaining consolidation and flow characteristics in different directions is used.
\end{abstract}

Key words: vertical permeability, horizontal permeability, non-linear flow characteristics, peat

\section{INTRODUCTION}

The permeability properties are very important in the consolidation process. In the stress-strain relationship, not only the value but also the curve of this characteristic are necessary to model the deformation, both in the vertical and horizontal direction. The organic subsoil, such as peat, is very often located in the engineering depth level under structures, such as dikes, barriers, dams and road embankments (Wolski et al. 1991). During the deformation process under load the shear strength increases which creates the embankment stability. The consolidation process depends on the distribution of the water pore pressure, which is connected to permeability. The soft organic subsoil during consolidation process significantly changes the porosity, which results in the change of flow characteristics. When the flow velocity of the pore water decreases substantially, the consolidation process increases in time.

In order to predict the real time of soil consolidation the coefficient of consolidation should not be constant. When 
it comes to the real, this coefficient varies due compressibility and permeability changes with growing effective stresses (Malinowska 2012). Acceleration of the consolidation process is much greater in the later phase of consolidation when the permeability of organic soils is essentially diminished (Koda and Szymański 1990, Koda et al. 1993). The latest research also shows that the permeability can be reduced by applying of biocementation for organic soils (Sidik et al. 2014).

The consolidation process is directly connected with the flow velocity in the subsoil under different loading. The literature review confirmed the anisotropic permeability and also the influence of non-Darcian flow on the consolidation process, in some soft subsoils (Hansbo 1960, 1997, 2003, 2005, Malinowska et al. 2011, 2014).

Vertical and horizontal laboratory permeability measurements in clay soils using the direct laboratory measurement of $k_{h}$ and $k_{v}$ enable a better estimation of field consolidation behavior to be made in soils with either marked creep properties or a more pervious macro structure (Wilkinson and Shipley 1972). Szymański (1991) considered some peat non-linear relationships. Also the peat anisotropic permeability was showed. Zhu and Yin (2004) considered the influence of the vertical and horizontal drainage smear effects into the consolidation process under ramp loading and the new normalized time factor $(T)$, was suggested. Scholes et al. (2007) analyzed the permeability anisotropy due to consoli- dation of compressible porous media using compression-permeability cells modified for use at elevated temperatures. The model for lignite, that allows the development of anisotropy to be predicted as a function of sample compression or void ratio, was proposed. Nevertheless, the moisture reduction effects were not calculated at this model. Compression and permeability anisotropy of some peaty soils (H3-H6) was studied by O'Kelly (2006, 2007). The empirical correlation after Azzouz et al. (1976) was found to predict more reliably the field compression. It was showed that the horizontal-to-vertical ratio $(r k)$ is in the range of 1.0 to 1.7 . The permeability ratio was found to increase with increasing effective stress (O’Kelly 2006, 2007).

For further investigations and predictions of stress-strain relationships in soft peat subsoil the anisotropy and non-Darcian flow should be considered in the consolidation model.

\section{MATERIAL AND METHODS}

To obtain the water flow characteristics in soft organic subsoil during laboratory tests it is necessary to model the in situ conditions with consideration of very high water content (full saturation), very high deformations both in vertical and horizontal direction, effective stress and pore pressure range. One of very precise methods for obtaining flow characteristics in peats is the flow-pump technique (Malinowska 2011), but it does not allow to perform the test in different flow and drainage directions. In the anisotropic 
organic peats' structure the vertical and horizontal permeability should be considered. That is why, the Modified Rowe Cell Set is proposed (Fig. 1). direction. The back $(B P)$ pressure supports the pressure that is needed to make the effective stress. Also the direction of the drainage is simulated, at that time.

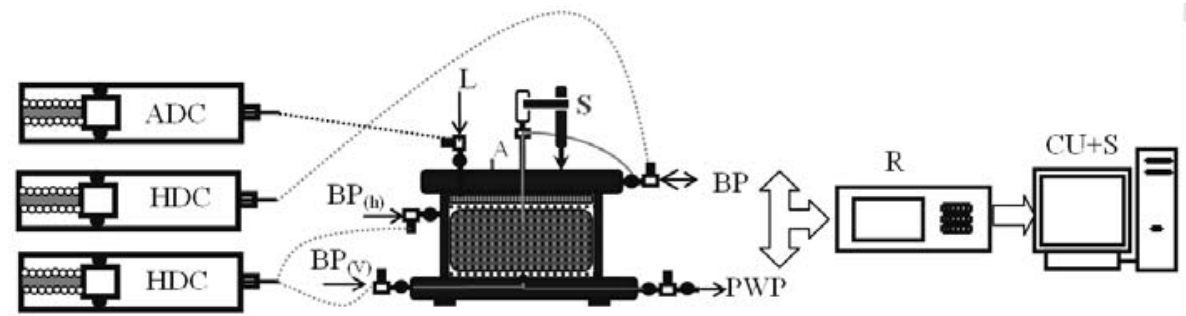

FIGURE 1. The Modified Rowe Cell Set: ADC - air device controller, HDC - hydraulic device controller, $B P_{(V)}$ - back pressure with vertical drainage, $B P_{(h)}$ - back pressure with horizontal drainage, $L$ - load, $A$ - air flow, $\mathrm{S}$ - settlement, $P W P$ - pore water pressure, $\mathrm{R}$ - recorder, $\mathrm{CU}+\mathrm{S}$ - computer unit with software

The Rowe Cell is used to obtain consolidation or permeability parameters (Rowe and Barden 1966). The Modified Rowe Cell Set is used to obtain consolidation and permeability parameters at the same time. Using the Modified Rowe Cell Set it is possible to control pneumatically load, vertical and horizontal drainage and to measure vertical deformations and pore water pressure during the consolidation and permeability test.

Also it is able to model different conditions of soil sample saturation. In the MRCS, the tested sample is loaded pneumatic by air pressure (ADC). The Rowe Cell can be connected to back pressure unit, working in vertical or horizontal
Drainage of the sample is controlled all the time, and the pore pressure and volume change are measured automatically. In each permeability stage, the hydraulic gradient is applied, and the flow velocity can be calculated. The ClispStudio Program registers the volume change in both hydraulic device controllers. For vertical permeability the pressure at the bottom soil sample $\left(P_{V 1}\right)$ should be bigger than the one on the top $(B P)$, because of the gravitation pressure (Fig. 2). For the horizontal permeability, the back pressure at the site $\left(P_{h}\right)$ should be bigger than the one on the bottom $\left(P_{V 1}\right)$, for the income flow, and smaller for the outcome flow (Fig. 3).
FIGURE 2. The Modified Row Cell set up for vertical permeability tests: $L$ - loading/stress value, $\mathrm{S}$ - settlement sensor, $A$ - air flow, $B P$ - back pressure for holding effective pressure or $P_{(V 1)}$ - pressure to set vertical flow, $P_{(h)}-$ pressure to set horizontal flow, $\mathrm{PWP}$ - pore water pressure sensor

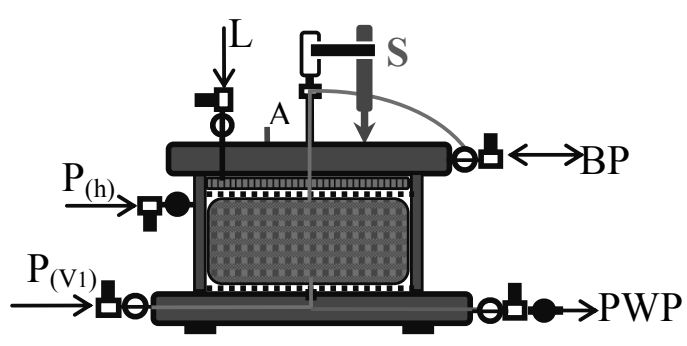




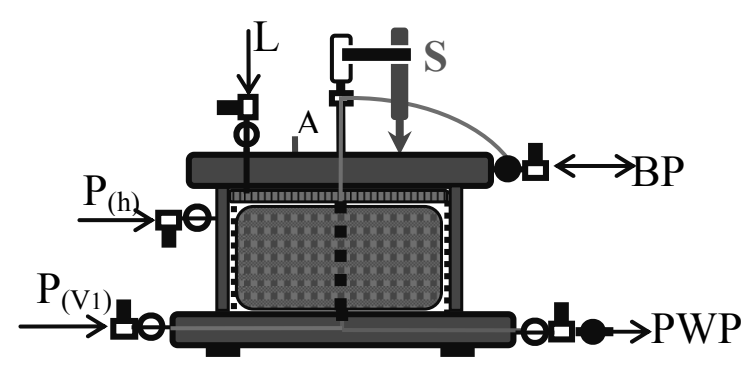

FIGURE 3. The Modified Row Cell set up for vertical permeability tests: $L$ - loading/stress value, $\mathrm{S}$ - settlement sensor, $A$ - air flow, $B P$ - back pressure for holding effective pressure, $P_{(V 1)}$ - pressure to set vertical flow or for outflow, $P_{(h)}$ - pressure to set horizontal flow, PWP - pore water pressure sensor

\section{RESULTS}

The laboratory tests were carried out on undisturbed peat samples taken from S2-express road located in Warsaw, Poland. The core of very soft, fine fibrous peat [H6] was taken from a depth of $1.8-2.5 \mathrm{~m}$.

The physical and mechanical properties of peaty soils are presented in Tables 1 and 2.

TABLE 1. Physical properties of peat taken from S2 tested area

\begin{tabular}{|l|c|}
\hline Physical properties & Peat_S2 \\
\hline Water content [\%] & 270 \\
Unit weight of solid particles & 16.6 \\
{$\left[\mathrm{kN} / \mathrm{m}^{3}\right]$} & \\
Unit weight $\left[\mathrm{kN} / \mathrm{m}^{3}\right]$ & $10-11$ \\
Dry unit weight $\left[\mathrm{kN} / \mathrm{m}^{3}\right]$ & 2.7 \\
Plasticity index [\%] & 132 \\
Organic matter content [\%] & $>20$ \\
Humification degree [\%] & 55 \\
Initial void ratio [-] & 3.5 \\
\hline
\end{tabular}

TABLE 2. Mechanical properties of peat taken from $\mathrm{S} 2$ tested area

\begin{tabular}{|l|c|}
\hline Mechanical properties & Peat \\
& $\mathrm{S} 2$ \\
\hline Friction angle $\left.{ }^{\circ}\right]$ & 31 \\
Cohesion [kPa] & 8.7 \\
Young's modulus for $\sigma^{\prime}{ }_{h}=30 \mathrm{kPa}[\mathrm{MPa}]$ & 6.6 \\
Young's modulus for $\sigma^{\prime}{ }_{h}=45 \mathrm{kPa}[\mathrm{MPa}]$ & 3.6 \\
Young's modulus for $\sigma^{\prime}{ }_{h}=60 \mathrm{kPa}[\mathrm{MPa}]$ & 3.15 \\
\hline
\end{tabular}

The consolidation and permeability parameters were performed in "free strain loading" conditions with different effective stress value; $2.5,5.0,10.0$, 25.0 , and $50 \mathrm{kPa}$.

The vertical and horizontal tests were obtained in the similar conditions to make a better comparison. Some of the test results are presented in this paper (Figs 4-13).

The characteristics of vertical and horizontal flow velocity in the relationship with hydraulic gradient are non-linear and depend on void ratio. The non-linearity is more obvious in the vertical direction and at small hydraulic gradients. 


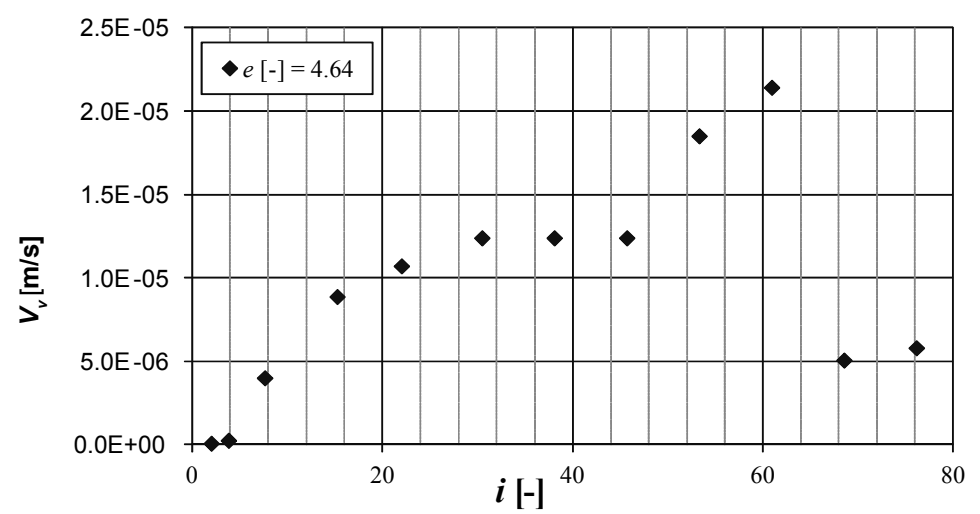

FIGURE 4. Vertical flow velocity versus hydraulic gradient data from MRCS tests for: $L=42.5 \mathrm{kPa}$, $B P=40 \mathrm{kPa}, \sigma_{v}{ }^{\prime}=2.5 \mathrm{kPa}$

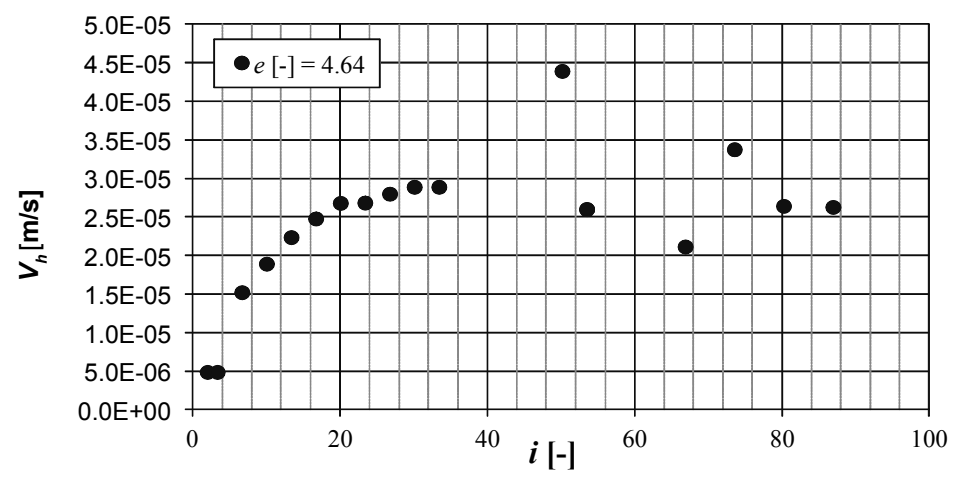

FIGURE 5. Horizontal flow velocity versus hydraulic gradient data from MRCS tests for: $L=42.5 \mathrm{kPa}$, $B P=40 \mathrm{kPa}, \sigma_{h}{ }^{\prime}=2.5 \mathrm{kPa}$

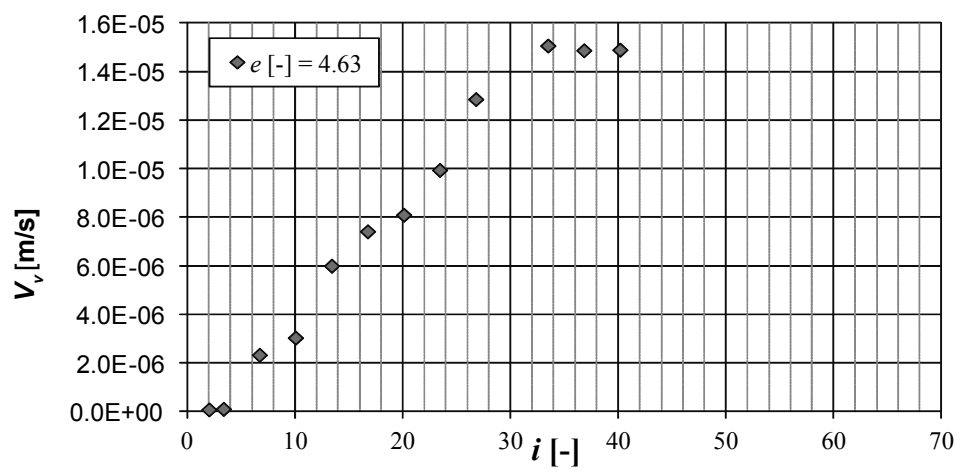

FIGURE 6. Vertical flow velocity versus hydraulic gradient data from MRCS tests for: $L=60 \mathrm{kPa}$, $B P=55 \mathrm{kPa}, \sigma_{v}^{\prime}=5 \mathrm{kPa}$ 


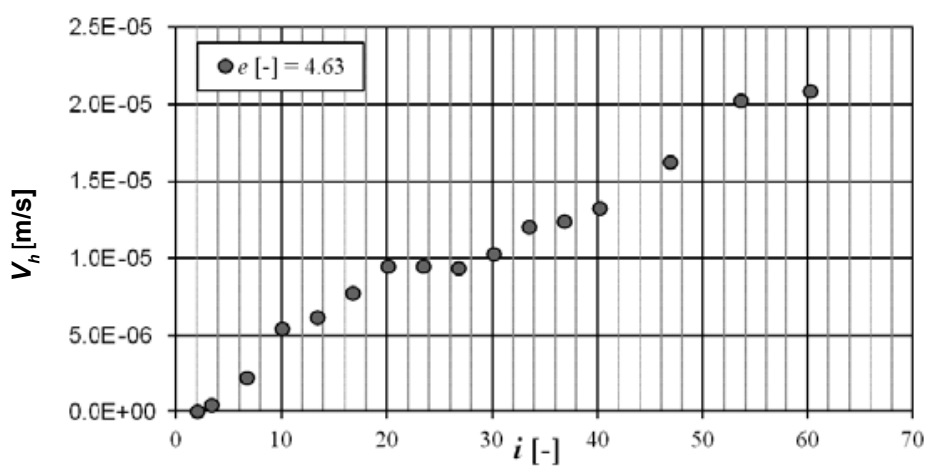

FIGURE 7. Horizontal flow velocity versus hydraulic gradient data from MRCS tests for: $L=60 \mathrm{kPa}$, $B P=55 \mathrm{kPa}, \sigma_{h}{ }^{\prime}=5 \mathrm{kPa}$

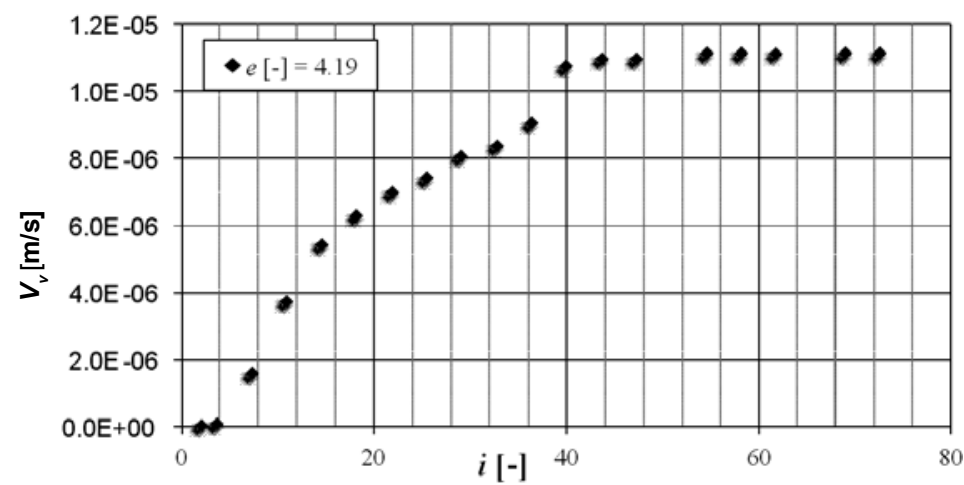

FIGURE 8. Vertical flow velocity versus hydraulic gradient data from MRCS tests for: $L=100 \mathrm{kPa}$, $B P=90 \mathrm{kPa}, \sigma_{v}{ }^{\prime}=10 \mathrm{kPa}$

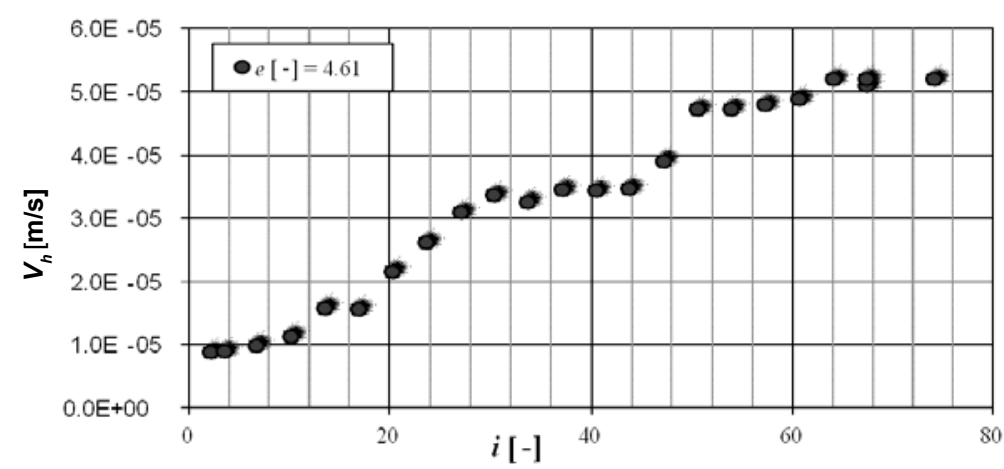

FIGURE 9. Horizontal flow velocity versus hydraulic gradient data from MRCS tests for: $L=100 \mathrm{kPa}$, $B P=90 \mathrm{kPa}, \sigma_{h}{ }^{\prime}=10 \mathrm{kPa}$ 


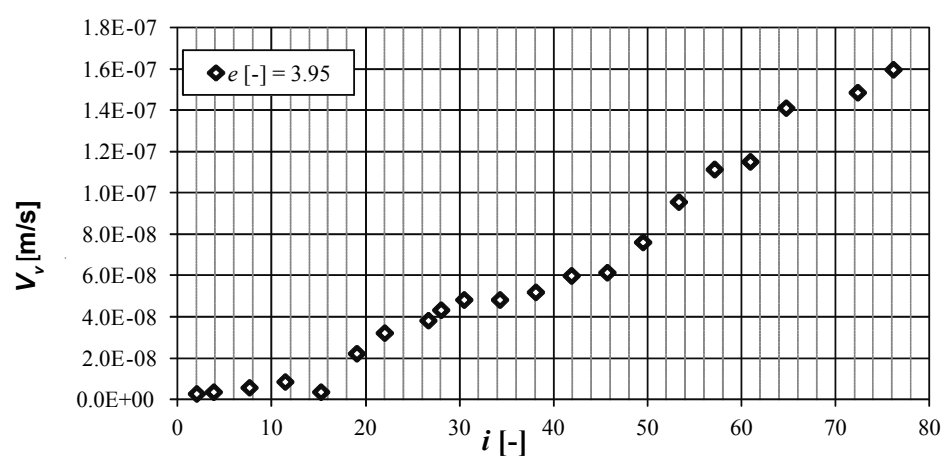

FIGURE 10. Vertical flow velocity versus hydraulic gradient data from MRCS tests for: $L=55 \mathrm{kPa}$, $B P=30 \mathrm{kPa}, \sigma_{v}{ }^{\prime}=25 \mathrm{kPa}$

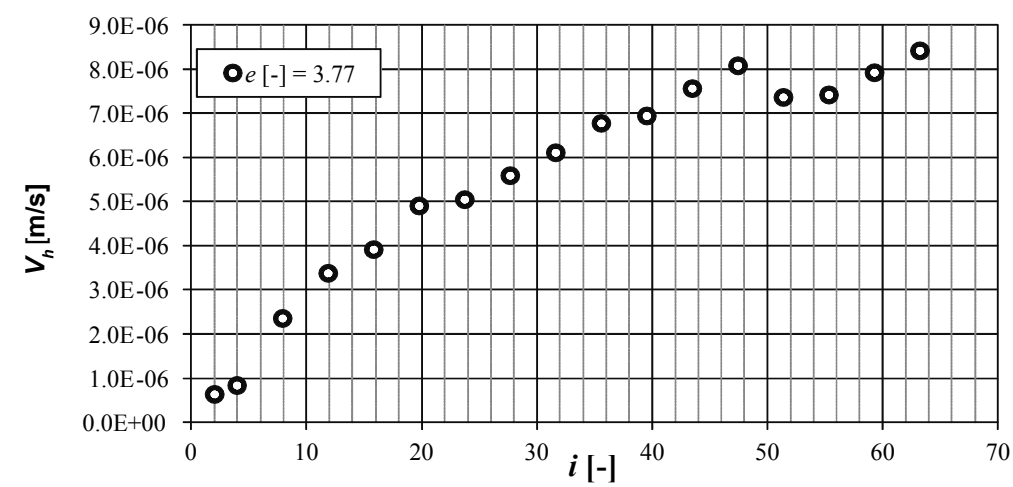

FIGURE 11. Horizontal flow velocity versus hydraulic gradient data from MRCS tests for: $L=55 \mathrm{kPa}$, $B P=30 \mathrm{kPa}, \sigma_{h}{ }^{\prime}=25 \mathrm{kPa}$

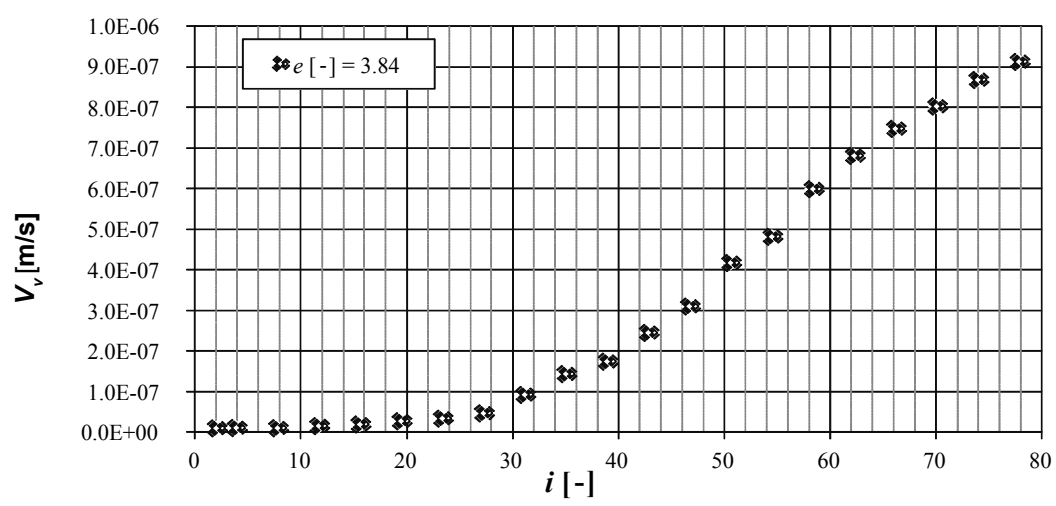

FIGURE 12. Vertical flow velocity versus hydraulic gradient data from MRCS tests for: $L=150 \mathrm{kPa}$, $B P=100 \mathrm{kPa}, \sigma_{v}{ }^{\prime}=50 \mathrm{kPa}$ 


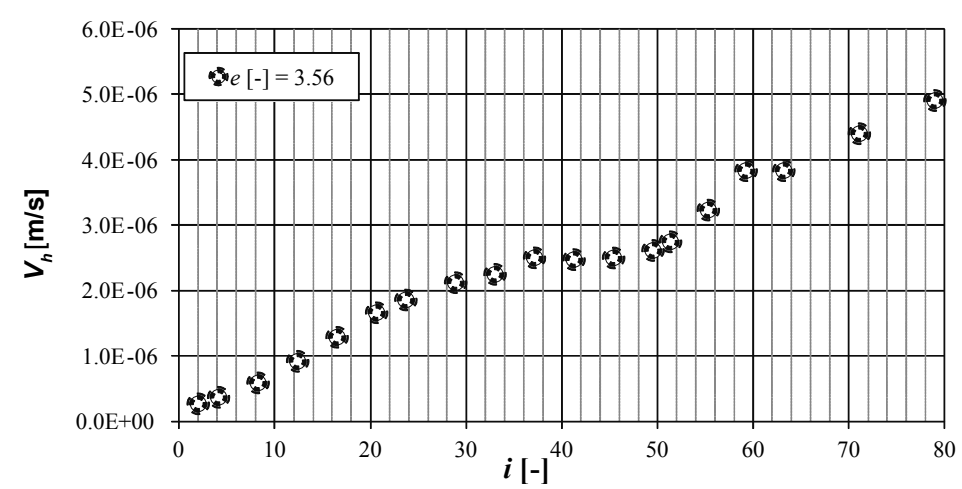

FIGURE 13. Horizontal flow velocity versus hydraulic gradient data from MRCS tests for: $L=150 \mathrm{kPa}$, $B P=100 \mathrm{kPa}, \sigma_{h}{ }^{\prime}=50 \mathrm{kPa}$

\section{CONCLUSION}

In this paper, vertical and horizontal permeability measurements and non-linear flow characteristics in organic soils considering variations in porosity are presented. The new Modified Row Cell Set method is proposed to model in situ flow rate in fully saturated conditions in vertical and horizontal direction. The settlement, pore water pressure, and back pressure in both directions is checked and analyzed during the test.

Based on the presented results the following conclusions can be drawn:

1. When it comes to organic soil it is necessary to take into account porosity and flow velocity changes during consolidation process.

2. Flow characteristics are anisotropic and non-linear and depend on porosity and hydraulic gradient.

3. To predict the consolidation process, the non-linear stress-strain, and non-linear, and anisotropic flow characteristics should be taken into the consideration.
4. The laboratory coefficient of vertical permeability changes dramatically and is one hundred times lower than coefficient of horizontal permeability.

\section{REFERENCES}

AZZOUZ A.S., KRIZEK R.J., COROTIS R.B. 1976: regression analysis of soil compressibillity. Soil and Foundations 16 (2), 19-29.

HANSBO S. 1960: Consolidation of clay with special reference to influence of vertical sand drains. Swedish Geotechnical Institute Proceeding 18, 45-50.

HANSBO S. 1997: Aspects of vertical drain design: Darcian or non-Darcian flow. Geotechnique 47 (5), 983-992.

HANSBO S. 2003: Deviation from Darcy's law observed in one-dimensional consolidation. Geotechnique 53 (6), 601-605.

HANSBO S. 2005: Experience of consolidation process from test areas with and without vertical drains. Elsevier Geo-Engineering Book Series 3, 3-49.

KODA E., SZYMAŃSKI A. 1990: Prediction of settlement of an embankment subsoil with vertical drains. Annals of Warsaw Agricultural University - SGGW. Land Reclamation 25, 3-12.

KODA E. SZYMAŃSKI A., WOLSKI W. 1993: Field and laboratory experience with the use 
of strip drains in organic soils. Canadian Geotechnical Journal 30 (2), 308-318.

MALINOWSKA E.E. 2011: Flow-pump technique as a constant velocity method of flow measurement in soft organic soils. Electronic Journal of Polish Agricultural Universities, Civil Engineering 14 (4), \#06.

MALINOWSKA E.E. 2012: Determination of the coefficient of consolidation in soft organic soils using ACONS. Annals of Warsaw University of Life Sciences - SGGW. Land Reclamation 44 (2), 133-142.

MALINOWSKA E.E., SZYMAŃSKI A., SAS W. 2011: Estimation of flow characteristics in peat. ASTM Inter. Geotechnical Testing Journal 34 (3), 250-254.

MALINOWSKA E.E. BURSA B.A., SZYMAŃSKI A. 2014: Derivation of consolidation partial differential equations with non-linear flow characteristics on organic soil example. Annals of Warsaw University of Life Sciences - SGGW. Land Reclamation 46 (4), 309-316.

O'KELLY B.C. 2006: Compression and consolidation anisotropy of some soft soils. Geotechnical and Geological Engineering 24, 1715-1728.

O'KELLY B.C. 2007: Compressibility and permeability anisotropy of some peaty soils. Proceedings of the 60th Canadian Geotechnical Conference, Ottawa. Breaking Ground in the Nation's Capital, The Diamond Jubilee.

ROWE P.W., BARDEN L. 1966: A new consolidation cell. Geotechnique 16 (2), 162-170.

SCHOLES O.N., CLAYTON S.A., HOADLEY A.F.A., TIU C. 2007: Permeability anisotropy due to consolidation of compressible porous media. Transp. Porous Med. 68, 365-387.

SIDIK W.S. CANAKCI H. KILIC I.H., CELIK F. 2014: Applicability of biocementation for organic soils and its effect on permeability. Geomechanics and Engineering (6), 649-663.

SZYMAŃSKI A. 1991: The factors determining the deformations analysis of organic subsoil under embankment. Treatises and Monographs SGGW No 133. Wydawnictwo SGGW, Warsaw.

WILKINSON W.B., SHIPLEY E.L. 1972: Vertical and Horizontal Laboratory Permeability Measurements in Clay Soils. Developments in Soil Science 2, 85-298.
WOLSKI W. SZYMAŃSKI A., KODA E. 1991: Efficiency of strip drains In an embankment dam foundation soil. XVII Congres des Grands Barrages, Vienn, Q.67, R.3, 63-70.

ZHU G., YIN J. 2004: Consolidation analysis of soil with vertical and horizontal drainage under ramp loading considering smear effects. Geotextiles and Geomembranes 22, 63-74.

Streszczenie: Pionowe i poziome pomiary przepuszczalności $w$ gruntach organicznych. W artykule została przedstawiona metodyka pomiaru przepuszczalności w kierunkach pionowym i poziomym. Ocena anizotropii przepuszczalności, szczególnie w słabonośnych gruntach organicznych, wymaga zastosowania specjalistycznego sprzętu i właściwej analizy otrzymanych wyników. Podczas obciążania podłoża organicznego nasypem budowlanym zmniejsza się wskaźnik porowatości, co powoduje zmianę przepuszczalności gruntu. Owa zmiana przepuszczalności znacząco wpływa na przebieg procesu konsolidacji. W opisie modelu deformacji organicznego podłoża słabonośnego należy brać pod uwagę zarówno nieliniowość zależności naprężenie-odkształcenie, jak nieliniowość i anizotropię przepływu. W celu uzyskania parametrów przepływu w kierunkach pionowym i poziomym została zastosowana metoda zmodyfikowanego zestawu komory Rowe'a (MRCS).

Stowa kluczowe: przepływ pionowy, przepływ poziomy, nieliniowe charakterystyki przepływu, grunty organiczne

\section{MS. received May 2015}

\section{Authors' address:}

Edyta E. Malinowska

Laboratorium - Centrum Wodne SGGW

ul. Ciszewskiego 6, 02-776 Warszawa,

Poland

e-mail: edyta_malinowska@sggw.pl alojzy_szymanski@sggw.pl 